\title{
PSYCHE.
}

\section{THE SPECIES OF CIRCOTETTIX, A NORTH AMERICAN GENUS OF OEDIPODINAE.}

BY SAMUEL H. SCUDDER, CAMBRIDGE, MASS.

Circotettix was established by me in 1876 upon Oedipoda undulata Thom.; and two other species, one of them then undescribed, were mentioned as belonging to it. In the same year Thomas described an additional species and five years later I published the undescribed species above mentioned. In $\mathrm{r} 884$ Saussure added two more and revised the whole genus (Prodr. Oedip.) and afterwards described a sixth species in his Additamenti. Since then Bruner has described several species, referring some of them here and some elsewhere. In my recent Catalogue of N. A. Orthoptera eleven species are listed, but since its publication I have undertaken a new study of the species, necessitating some changes, the result of which appears in the subjoined table of ten species, to which I have added a few notes, principally on distribution.

In this table I have distinguished the radials (radiate veins) of the anal area of the hind wings, as superjacent or sub- jacent, according as they rise above or fall below the general plane of the wing; the first superjacent radial terminates in the middle of the axillary lobe.

In the last two species, aberrant members of the genus, the arrangement and relations of the first subjacent and superjacent radials of the hind wings closely resemble the same features in C. verruculatus, next which they are placed.

Oedipoda sparsa Thom., which is probably a Circotettix, is not included in the table, as I have not seen it recently and it is at present indeterminable. The type is lost and although the figure given in Wheeler's report shows hind wings of a shape hardly consistent with Circotettix, yet when the genus was established I had evidently seen the species and regarded it as a Circotettix. Saussure also so regarded it.

Circotettix in the New World is represented by the genus Bryodema in the Old World, but the former is much the richer in species. 
Table of the Species of Circotettix.

$A^{1}$. Insects of medium or large size. Pronotum acutangulate or rectangulate behind, rarely feebly obtusangulate; first (humeral) lobe of hind wings distinctly elongated, protruding distinctly beyond the general curve of the outer margin, which is generally lobate.

$b^{1}$. Tegmina relatively broad; general form of hind wings subfalcate, the curve of the outer margin distinctly sinuate, the radiate field very broad and full, and the humeral field relatively broad.

$c^{1}$. Hind wings fuscous or else thalassine at base, rarely hyaline, and not crossed by a mesial fuscous band.

$d^{1}$. Hind wings fuscous at base or hyaline with very heavily infuscated radiate veins; upper fork of first subjacent radial free, and relatively distant from the first superjacent radial.

$e^{1}$. Of relatively small size, the tegmina hardly exceeding $25 \mathrm{~mm}$. in length; hind wings wholly blackish fuscous or with only the apical fourth or less hyaline.

I. maculatus. $e^{2}$. Of relatively large size, the tegmina nearly $35 \mathrm{~mm}$.. in length; hind wings hyaline with very heavily infuscated radials and the whole base generally black to a varying distance up to more than half of the wing.

2. carlinianus.

$d^{2}$. Whole of hind wings thalassine; upper fork of first subjacent radial running very close to the first superjacent radial and finally uniting with it.

3. thalassinus.

$c^{2}$. Hind wings more or less sulphureous* at base, and more or less distinctly crossed by a mesial fuscous band.

$d^{1}$. Basal half of hind wings with very weak coloring, almost hyaline ; upper branch of first subjacent radial free; apical margin of axillary lobe strongly arcuate, the lobes below it distinctly emarginate .

4. lobatus.

$d^{2}$. Basal half of hind wings with rather strong coloring; upper branch of first subjacent radial uniting with the first superjacent radial; apical margin of axillary lobe obliquely truncate, but little arcuate, the remaining lobes apically subtruncate.

$e^{1}$. Markings of tegmina less conspicuous, and more distinctly clustered into three transverse fasciae; upper branch of first subjacent radial run-

*C. lobatus is described by Saussure as having the basal half of the hind wings "dilute hyalino-sulfurescens vel thalassina." I have seen none with the latter coloring, but it may easily be distinguished from the species of the preceding alternate category by its transverse mesial band, though this is incomplete. 
ning for some distance beside and close to the first superjacent radial, before uniting abruptly with it; hind tibiae pale dull yellow, but black at base

5. undulatus. $e^{2}$. Markings of tegmina generally very conspicuous and pretty uniformly distributed; upper branch of first subjacent radial uniting at once (as an oblique cross vein) with the first superjacent radial, which is of about the same thickness as the next superjacent radial; hind tibiae dark glaucous, with a pale yellow post-basal annulus and a black base . 6. shastanus. $b^{2}$. Tegmina relatively narrow; hind wings narrower than in the alternate category, with but feeble indication of falcation, the radiate field scarcely broader than is usual in Trimerotropis, the humeral field relatively narrow, the basal half sulphureous, beyond more or less infuscated.

$c^{1}$. Lateral foveolae of the head triangular but distinctly elongate; hind wings wholly infuscated in apical half, though of deeper intensity next the sulphureous base, the costal stigma generally deeply infumated; hind tibiae plumbeoglaucous, with a post-basal yellowish annulus . . . 7. suffusus. $c^{2}$. Lateral foveolae of the head equilateral or nearly so; hind wings infuscated beyond the sulphureous base only in a band of irregular width across the middle.and at the apex, the intervening region hyaline with fuscous veins, the costal stigma luteous though black margined; hind tibiae yellowish with black base and apex, and with mesial fuscous cloudings beneath.

8. verruculatus.

$A$. Insects of relatively small size. Pronotum obtusangulate behind, generally distinctly so; front (humeral) lobe of hind wings not protruding in any noticeable way beyond the general curve of the outer margin, which is not or barely lobate.

$b^{1}$. Tegmina distinctly flecked with fuscous; hind wings broad, hyaline, with luteous marginal stigma; hind tibiae dull yellow . . . 9. perplexus. $b^{2}$. Tegmina obscurely clouded with fuscous; hind wings narrow, crossed by a strongly arcuate narrow fuscous band and with fuscous marginal stigma, the base very faintly washed with greenish yellow; hind tibiae pale glaucous.

Io. occidentalis.

\section{Circotettix maculatus.}

Circotettix maculatus Scudd.!, Rep. U. S. ent. comm., ii, App., 26, pl. I7, fig. го (г88г) ; Sauss., Prodr. Oedip. г76I77 (1884).

The specimens I have seen come from Nevada, July (O. S. Westcott). Mts. near Lake Tahoe, Nev., Oct. (H. W. Henshaw - Wheeler's expl.), Sierra Nevada, July I7-22 (Baron Osten Sacken), Truckee, Cal., Oct. ro (Scudder), Tahoe Co. Cal. (Stanf. Univ.), and Cloud's Rest, Yosemite Valley, Cal., Aug. I 2 (A. P. Morse). 


\section{Circotettix carlinianus.}

Oedipoda carliniana Thom., Proc. acad. nat. sc. Philad., I870, 8I (1870).

Oedipoda carlingiana Thom., Ann. rep. U. S. geol. surv. terr., II, 265, 275 (187 I); Thom., Syn. Acrid. N. A., I26 (1873).

Circotettix carlingianus Thom., Proc. Dav. acad. nat. sc., I, 254-255 (1876); Sauss., Prodr. Oedip., r 76 (1884).

Circotettix carlinianus Scudd., Proc. Dav. acad. nat. sc., VIII, 42 (I900).

Named, according to Thomas, after Col. Carlin. The $g$ has entered the name apparently as a typographical error.

This species varies greatly in the coloring of the wings as regards the extension from the base of the fuscous infumation; it may cover more than half the wing, or it may be entirely absent except from the veins, but in the latter case there is often a faint indication of the upper portion of a median cross-band, as in some other species; this is especially the case with specimens from British Columbia, but is also seen in one from southern Colorado. British Columbia specimens are also smaller than those from further south.

In my notes on the songs of our Orthoptera given in the 23d Report of the Entomological society of Ontario, p. 78 , I have made for this species statements which belong instead to $C$. undulatus. The present species is by no means so noisy, remaining only five or six seconds in the air during its flights, and making a rustling sound rather than a crackle, - in fact more closely resembling the faint rustle of $C$. maculatus. I have before me specimens from the following localities, all, unless otherwise specified, taken by myself :- Colorado, 7-80oo' (Morrison); Garland, Col., 800o', Aug. 28-29; Pueblo, Col., July 8-9; South Park, Col., 8-roooo', Aug. I 1 -I6 ; Douglas Creek, Col., Aug. 22 ; White River, Col., July 24-Aug. I3; Green River, Wyo., July 2 I-3 I ; Alkali Station, Wyo., 600o', July 27; Fossil, Wyo., Sept. 2 ; Parowan, Utah, 600o', July 3-ro (Palmer); Reno, Nev., Aug. I 8 (Packard); British Columbia and Vancouver Is. (Crotch). Other regions from which it has been reported are: from Ft. Benton, Mont., to Ft. McLeod, Alberta (Bruner), Montana (Thomas, Bruner), the Yellowstone region (Bruner, Saussure), Yakima Wash., and northwestern Nebraska (Bruner).

\section{Circotettix thalassinus.}

Circotettix thalassinus Sauss., Prodr. Oedip., I77-178 (1884).

I have received this species only from Nevada (H. Edwards), from which state it was described by Saussure, and from Tahoe Co., Cal., August (Mus. Leland Stanford Univ.).

\section{Circotettix lobatus.}

Circotettix lohatus Sauss., Add. prodr. Oedip., 65-66, pl., fig. 5 (1888).

Circotettix lapidicola Brun.!, Proc. U. S. nat. mus., XII, 75-76 (1890).

My single specimen was received 
from Bruner, and comes from Salmon City, Idaho. Saussure's specimens come from Colorado. The synonymy is pretty evident.

\section{Circotettix undulatus.}

Oedipoda undulata Thom., Ann. rep. U. S. geol. surv. terr., V, 460 (187 I); Thom., Syn. Acrid. N. A., 125-126 (1873).

Circotettix undulatus Scudd., Bull. U. S. geol. surv. terr., II, 265 (1876); Sauss., Prodr. Oedip., I 77 (1884); Sauss., Add. prodr. Oedip., 65 , pl. fig. 6 (1888).

To this species belong the remarks I have made under $C$. carlinianus (Rep. ent. soc. Ont., XXIII, 78) concerning the noise made by the insect in flight.

Specimens at hand, all taken by myself unless otherwise indicated, come from the top of the range between the Sapello and Pecos rivers, N. Mex. Irooo', Aug. (Cockerell); Colorado (Morrison); Garland, Col., 800o', Aug. 28-29; Sierra Blanca, Col., below timber line, I I-1 2000', Aug. 29; Florissant, Col., 8000', June, Aug. I7-22 ; South Park, Col., 8-roooo', Aug. I I-I 5; above Alma, Col., roooo', Aug. I3-I4; Empire City, Col. (Palmer); Georgetown, Col., 7500-8500', July II -18 ; Grand River, Col., Aug.22 ; Roan Mts., Col., Aug. r6I7; Provo, Utah, Aug. 23-24; American Fork Cañon, Utah, 9500', Aug. 2-3; Wahsatch Mts. near Beaver, Utah, July I2-18 (Palmer); Alkali Station, Wyo., July 27 ; Fossil, Wyo., Sept. 2 ; Yellow- stone Park, Sept. 6-I 2. Other districts besides the above from which it has been reported are: Nebraska (Dodge, Bruner), Montana (Bruner), Nevada (Thomas, Saussure), Yakima, Wash. (Bruner), Victoria (Fletcher).

\section{Circotettix shastanus.}

Circotettix shastanus Brun., Proc. U. S. nat. mus., XII, 76-77 (1890).

Of rather slender form, compressed, faintly pubescent, brownish testaceous, heavily flecked especially on tegmina with dark or blackish fuscous; the pronotum typically with a large central spot above and a patch at the upper limit of the lateral lobes on the prozona; the tegmina heavily flecked almost uniformly throughout but especially on basal half with blackish fuscous, deeper in tint in southern examples, there being but faint traces of transverse fasciation. Head testaceous, all the carinae punctate with black, the fastigium of vertex shallow but with raised margins and a feeble median carina; antennae dull testaceous banded with fuscous. Pronotum posteriorly rectangulate, the margin of the process punctate or interrupted with black. Tegmina broad; hind wings subfalcate, pale sulphureous basally, this color often extending further along the rays, crossed just beyond the middle by an unequal, sometimes broken, more or less cloudy, fuscous band, sending a taenia nearly half way to the base in the humeral field, the apical portion of the wing hyaline with fuscous veins, the costal stigma infumate; form of the wings precisely as in C. undulatus, but the venation differing in that the upper branch of the first subjacent radial unites at birth, as an oblique cross-vein, with the first superjacent radial, in which point it differs from all the other species. Hind femora cinereo-testaceous, thrice fasciate with blackish fuscous ; 
hind tibiae dark glaucous, with a pale yellow post-basal annulus and a black base.

Length of body, $\delta, 26 \mathrm{~mm}$.,,$+ 30 \mathrm{~mm}$.; antennae, $\delta, 9.25 \mathrm{~mm}$., $\&$, Io $\mathrm{mm}$.; tegmina, $\delta, 29.5 \mathrm{~mm}$., $q, 29 \mathrm{~mm}$; hind tibiae, $\delta$ \% II $5 \mathrm{~mm}$.

8 ơ, I2 9 . Siskiyou, Or., Sept. 6; Yosemite Valley, Cal., Aug. I I, A. P. Morse.

I redescribe this species because I am not quite sure that it is identical with Bruner's $C$. shastanus. That was described from a single specimen from Shasta Co. Cal., which I have not seen, and which, if now in existence is in the national museum. Bruner describes the tegmina as agreeing in markings with those of his $C$. lapidicola ( $C$. lobatus Sauss.), but in their conspicuous mottling my specimens are widely different from a specimen of $C$. lapidicola sent me by Bruner, in which the markings are nearly obliterated. There is however a wide difference also in this respect between the specimens before me from Oregon and the Yosemite valley, the latter being far more distinctly mottled, so that I am inclined to lay little stress on this point. In the structural features of the wings, the specimens before me agree well with Bruner's description.

\section{Circotettix suffusus.}

Trimerotropis suffusus Scudd.!, Bull. U. S. geol. surv. terr., II, 265 (1876).

Circotettix suffusus Scudd., Proc. Davenp. acad. nat. sc., VIII, 43 (I900). Trimerotropis columbia Scudd.!, Rep. ent. soc. Ont., XXIII, 77 (1893).
Circotettix suffusus is a stepping stone toward the fallax group of Trimerotropis and is with difficulty separable from T. fallax; the veins of the hind wings are but little thickened and the markings of the wings are much the same. In $C$. suffusus, however, the infumation in the middle of the wings is generally deeper. To a less extent than in the other species of Circotettix, the cells of the outer half of the anal area are predominantly tranverse, while in $T$. fallax they are usually polygonal and subequal.

I have seen specimens from Vancouver Isl. (Edwards, Crotch), British Columbia (Crotch), Nanaimo and Sandon B. C. (Fletcher), Oregon City, Or., July (Harford), Sierra Nevada (Edwards), vicinity of Lake Tahoe, Nev., Sept., Oct. (Henshaw - Wheeler's expl.), and Colorado, 8500',-I0000' (Morrison); and have taken it myself at American Fork Cañon, Utah, 9500', Aug. 23, Garland, Col., 80oo', Aug. 28-29, Manitou, Col., 630o', Aug. 24-25, Florissant, Col., 800o', Aug. I 7-22, Alma, Col., roooo', Aug. I3-I4, north fork of South Platte, Col., Aug. Io, Evanston, Wyo., 680o', Aug. 6, and Yellowstone Park, Sept. 6I2. It has also been reported from Washington (Bruner), and wrongly by me from Mt. Shasta, Cala., the reference being properly to $T$. fallax.

\section{Circotettix verruculatus.}

Locusta verruculatá Kirby, Faun. bor. amer., IV, 250 (1837).

Oedipoda verruculata Scudd., Can. 
nat., VII, 287 (1862); Thom., Syn. Acrid. N. A., II5-116 (1873).

Trimerotropis verruculata Scudd., Hitchc., Rep. geol. N. H., I, 377, fig. 57 (1874).

Circotettix verruculatus Sauss., Prodr. Oedip., I75-176 (1884).

Locusta latipennis Harr., Ins. inj. veg., 144 (184I).

I have seen specimens from Nova Scotia (Piers); Mt. Desert Isl. and Moosehead Lake, Me. (Scudder); White Mts. N. H., valleys and summits, late July and early August (Scudder); Sudbury, Vt. (Scudder); Princeton and summit of Graylock, Mass. (Scudder). Summit of Mt. Tom, Mass. (Shurtleff); Chateaugay Lake, Adirondacks, N. Y. 2000', (Bowditch); Montreal (Caulfield); Prescott (Billings); Sudbury (Scudder), and DeGrassi Point, Ont., July $3 \mathbf{I}$ (Walker); southern Illinois (Thomas); Red River (Gunn), and Dufferin, Manit. (Dawson); Wigwam Point, Lake Winnipeg (Scudder); British Columbia (Crotch); Vancouver Isl. (Edwards); and the upper McKenzie River, Great Bear Lake and Arctic America (Kennicott). It has further been reported from New Haven, Conn. (Smith); vicinity New York City (Beutenmuller); New Jersey (Smith); Quebec (Scudder) and Saguenay River (Norton); Lake Simcoe, northern Ontario and Lake Superior (Walker); Minnesota (Lugger); Illinois and Montana (McNeill); Nebraska (Bruner); Colorado (Saussure, Cockerell); Dakota and Montana (Bruner); California
(Saussure); Saskatchewan region (Scudder); and Lat. $57^{\circ}$ [Athabasca] (Kirby). It is also credited to Mississippi by Saussure, but surely by error. Probably the references to Colorado and Calfornia belong to $C$. suffusus.

\section{Circotettix perplexus.}

Trimerotropis perplexa Brun.l, Proc. U. S. nat. mus., XII, 74-75 (I890).

Mr. Bruner has sent me one of his types from Chadron, Nebr., Aug. It has not been reported from any other point.

\section{ro. Circotettix occidentalis.}

Oedipoda (?) occidentalis Brun.!, Proc. U. S. nat. mus., XII, 77-78, pl. r, fig. 7 (I890).

Circotettix(?) occidentalis Scudd., Proc. Dav. acad. nat. sc., VIII, 43 (1900).

It was described from the vicinity of San Francisco, Cal., November, and has not been reported elsewhere. I owe my specimens to Professor Bruner.

\section{I. Circotettix sparsus.}

Oedipoda sparsa Thom., Rep. U. S. geol. surv. w. Io० mer. V, 883 , pl. 45, fig. 6 (1875).

Circotettix sparsus Scudd., Bull. U. S. geol. surv. terr., II, 265 (I876.)

Described by Thomas from New Mexico and since 1876 unrecognized. See a paragraph above, just preceding the table. 

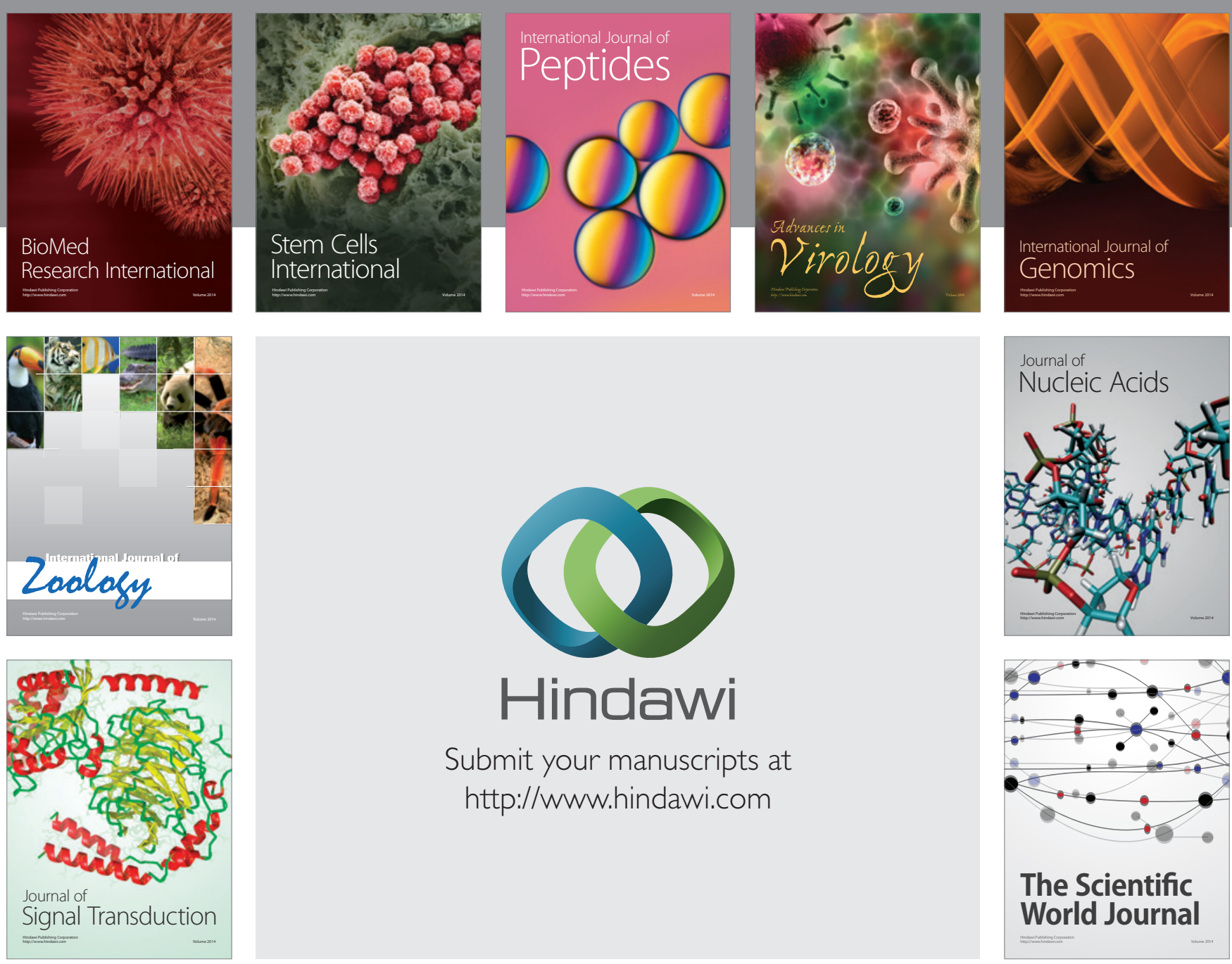

Submit your manuscripts at

http://www.hindawi.com
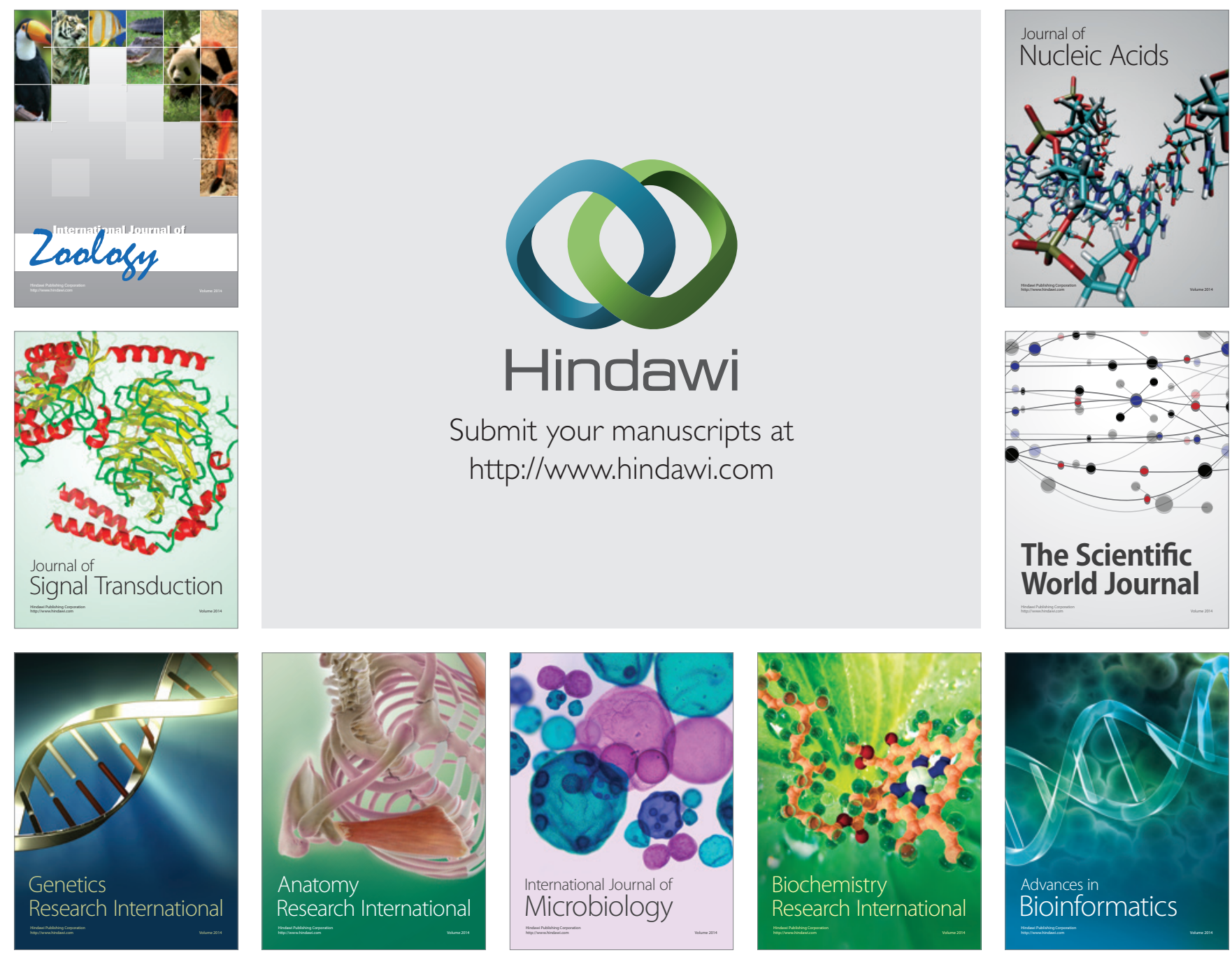

The Scientific World Journal
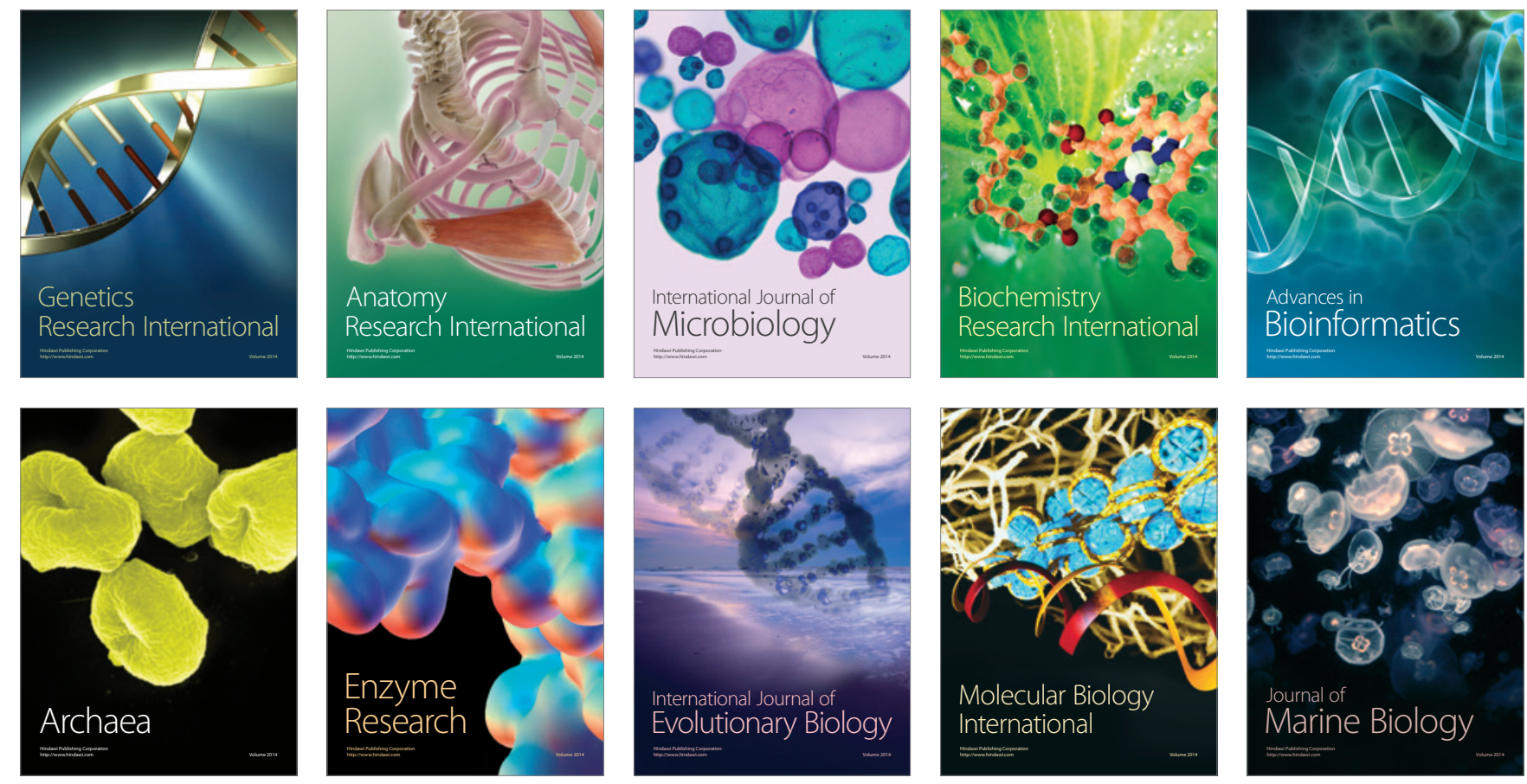